\title{
Sociabilidad, propaganda y cultura: los centros de trabajadores en el norte argentino (Tucumán y Santiago del Estero, 1897-1907)
}

Vanesa Ester Teitelbaum

Resumen: El propósito de esta contribución consiste en examinar las prácticas de sociabilidad, propaganda y cultura desarrolladas por los centros obreros en el norte argentino, particularmente en Tucumán y Santiago del Estero. El trabajo comienza con una descripción acerca de la composición, el liderazgo y las principales actividades puestas en marcha por estos espacios. Posteriormente, el estudio se centra en el análisis de las fiestas, aspecto esencial de la vida asociativa, que permitía integrar los fines de recreación con las consignas de difusión y propaganda dirigida a construir una militancia en el mundo del trabajo. Finalmente, exploramos las iniciativas desplegadas por los centros obreros para concretar aspiraciones medulares de la vida asociativa, como eran las bibliotecas y el establecimiento de escuelas que ofrecieran una educación alternativa a la impartida por el Estado.

Palabras claves: Socialismo; 10 de mayo; Movimiento obrero.

\begin{abstract}
The purpose of this contribution is to examine the practices of sociability, propaganda and culture developed by the workers' centers in northern Argentina, particularly in Tucumán and Santiago del Estero. The work begins with a description of the composition, leadership and the main activities implemented by these spaces. Subsequently, the study focuses on the analysis of the parties, an essential aspect of community life, allowing integration of recreation with the slogans and propaganda broadcast aimed at building a militant in the world of work. Finally, we explore the initiatives undertaken by the workers' centersto realize core aspirations of community life, as were thelibraries and the establishment of schools offeringalternative education to that provided by the State.
\end{abstract}

Keywords: Socialism; 1 May; The labor movement.

Resumo: O objetivo desta contribuição é examinar as práticas de propaganda, sociabilidade e cultura desenvolvidas por centros de trabalhadores no norte da Argentina, particularmente em Tucumán e Santiago del Estero. O trabalho começa com uma descrição da composição, a liderança e as principais atividades implementadas por estes espaços. Posteriormente, o estudo centra-se na análise das partes, um aspecto essencial da vida da comunidade, permitindo a integração de recreação com os slogans e transmitem propaganda política visando a construção de um militante no mundo do trabalho. Finalmente, vamos explorar as iniciativas empreendidas pelos centros dos trabalhadores para realizar as aspirações fundamentais da vida da comunidade, assim como as bibliotecas e o estabelecimento de escolas que oferecem educação alternativa ao previsto pelo Estado.

Palavras-chave: Socialismo, 01 de maio; Movimento sindical.

Hacia finales del siglo XIX y primeros años del novecientos, en sintonía con lo que ocurría en otras regiones de Argentina, en el norte argentino - particularmente en Tucumán, Salta, Jujuy y Santiago del Estero - se crearon centros obreros al influjo del anarquismo y 
especialmente del socialismo, movimiento que alcanzó particular impacto en esta última provincia.

Una lectura de la prensa, ${ }^{1}$ completada con los testimonios de militantes y dirigentes obreros del periodo, ${ }^{2}$ reveló la importancia que adquirieron en esta trama asociativa el Centro Cosmopolita de Trabajadores y, posteriormente, el Centro Socialista, en Tucumán, ${ }^{3}$ así como los centros socialistas de Santiago del Estero, La Banda y Frías, localidades situadas en esta última provincia.

Con el propósito de avanzar en el conocimiento de la historia social, del trabajo y de los trabajadores en los umbrales del siglo $\mathrm{XX}$, en las páginas que siguen analizaremos las prácticas de sociabilidad, propaganda y cultura desarrolladas por estos espacios que, a pesar de su influencia, recibieron poca atención por parte de la historiografía regional. En particular, en esta contribución trataremos de aproximarnos a uno de los aspectos más significativos referidos a la vida asociativa: las fiestas, entendidas como una alternativa para el aprovechamiento del tiempo libre de los trabajadores en el marco de una empresa orientada a construir una militancia obrera. ${ }^{4}$

Desde esa perspectiva, podemos interpretar las numerosas veladas y tertulias literario-musicales organizadas por los centros de trabajadores en Tucumán y Santiago del Estero. Tal como era lo usual en las celebraciones del socialismo en Argentina, las veladas combinaban expresiones artísticos-culturales, como conferencias, obras de teatro, poesía, coros y orquestas, con números de entretenimiento como rifas y bailes, sin duda uno de los momentos más esperados y atractivos de las fiestas. ${ }^{5}$

\footnotetext{
${ }^{1}$ Esta investigación se basa, principalmente, en el estudio para el periodo 1896-1907 del semanario, y desde 1905 diario, La Vanguardia, portavoz oficial del Partido Socialista en Argentina. Esta información se complementó y contrastó con el examen de La Protesta Humana, uno de los principales órganos de expresión del anarquismo en Argentina, para los años 1898-1908. Asimismo, nos apoyamos en nuestro análisis sistemático de El Orden, que fue el principal diario de Tucumán durante el periodo estudiado y una publicación que alcanzó además un lugar central en la prensa regional de la época. Revisamos todos los números de $E I$ Orden para el periodo 1897-1911.

${ }^{2}$ En especial, nos sirvieron los testimonios de líderes del socialismo, como Nicolás Repetto, quien escribió sobre los centros obreros de Tucumán y de Santiago del Estero. REPETTO, Nicolás. Mi paso por la política. De Roca a Yrigoyen. Buenos Aires: Santiago Rueda Editor, 1956.

${ }^{3}$ Las primeras investigaciones sobre este tema se plasmaron en AUTOR, 2009, 2011a y 2011 b.

${ }^{4}$ En especial, nos apoyamos en los sugerentes análisis de SURIANO, Juan. Cultura y política libertaria en Buenos Aires, 1890-1910. Buenos Aires: Ediciones Manantial, 2001 y de MASES, Enrique, El tiempo libre de los trabajadores en la norpatagonia. De la cultura política, las prácticas recreativas y deportivas al disciplinamiento social 1900-1945. Quinto Sol, n. 9-10, Instituto de Estudios Socio-Históricos-Facultad de Ciencias Humanas, Universidad Nacional de La Pampa, 2005-2006, p. 73-97. Resultaron valiosos, además, aportes existentes para otras latitudes, como España, en especial, el trabajo de MORALES MUÑOZ, Manuel. Un espacio propio. Sociabilidad e identidad obrera en Andalucía. Historia Social, Valencia, n. 56, 2006, p. 53-69.

${ }^{5}$ En ese sentido, resultó sugerente el análisis de Joan Casanovas Codina, quien en su trabajo sobre los centros de trabajadores en Cuba explica que una de las principales actividades que desarrolló El Recreo de Obreros, una sociedad de "instrucción y recreo" que funcionó en la ciudad de La Habana desde 1879 a 1884, consistió en brindar veladas familiares compuestas por obras de teatro, conferencias, poesías y conciertos de música. "Casi siempre estas veladas finalizaban con un baile; sin duda la actividad del Recreo que más gustaba a los artesanos y sus familias", afirma el autor. CASANOVAS CODINA, Joan. El artesanado habanero y los orígenes del Círculo de Trabajadores. Historia Social, n. 31, 1998, p. 114.
} 
En especial, las celebraciones adquirían un notorio relieve durante la conmemoración del 10 de mayo, principal aniversario del movimiento obrero, que permitía a los líderes del mundo del trabajo reforzar sus labores para concientizar y difundir un ideario de lucha entre los trabajadores, acercándolos a su vez a las filas del anarquismo y en especial del socialismo, tendencia que lideró las actuaciones de los centros tucumanos y santiagueños.

En consonancia con el valor otorgado por las corrientes de izquierda en el mundo del trabajo a la instrucción, la educación y la lectura, los centros de trabajadores dirigieron sus esfuerzos a establecer salones de lectura, bibliotecas y escuelas. Dichas iniciativas son examinadas también en este estudio que incluye también, a modo de presentación, una descripción sobre aspectos vinculados con la composición, el liderazgo y las principales consignas seguidas por los centros obreros en Tucumán y Santiago del Estero.

\title{
1. INTEGRANTES, DIRIGENTES Y ACTIVIDADES DE LOS CENTROS OBREROS
}

Tras su visita al norte argentino en 1901, el militante y dirigente del socialismo Nicolás Repetto, aseguraba que

\begin{abstract}
Santiago y Tucumán ofrecen una característica económica común; la ausencia de la gran industria en sus centros urbanos. A excepción de algunos molinos, curtiembres y aserraderos, que aglomeran cierto número de obreros, la producción urbana reviste un carácter primitivo y está en manos de artesanos [...] La situación de este grupo industrial va tornándose cada vez más precaria, debido a la invasión cada día más creciente, de los productos manufacturados que impone el mercado de Buenos Aires.

Un segundo grupo está formado por los ferrocarrileros [...] La cultura y el nivel intelectual de estos trabajadores contrastan singularmente con los de otros grupos, y hace de ellos agentes muy aptos para la propagación de nuestras doctrinas [...] Un tercer grupo, el más numeroso, miserable y explotado, está formado por los peones del campo. En santiago cortan los árboles, hachean durmientes y postes, transportan, cargan y descargan la leña, etc. En Tucumán hacen la zafra, es decir, el corte de la caña de azúcar, cortan y transportan la leña, cultivan la caña, el arroz, etc. Difícilmente puede concebirse una situación más miserable de la que ha tocado en suerte a estos infelices. ${ }^{6}$
\end{abstract}

Luego de describir los principales grupos de trabajadores, Repetto se ocupó de subrayar en qué proporción intervienen en la composición de los diferentes centros y cuál es el carácter que han dado a la propaganda socialista. En ese sentido, afirmaba que

Entre los afiliados a los centros socialistas de Santiago y de Tucumán figura en primera fila un grupo de hombres que trabajan por cuenta propia: zapateros, sastres, plateros, tipógrafos, talabarteros, constructores de carros, peluqueros, pintores, etc. Vienen luego los ferrocarrileros: maquinistas, fogoneros, ajustadores, pintores, dibujantes, guardahilos, etc. En último término, un pequeñísimo grupo de

\footnotetext{
${ }^{6}$ REPETTO, Mi paso por la política..., op. cit., p. 40-41.
} 
asalariados al servicio de las pequeñas industrias urbanas. En el Centro Socialista de Frías (Santiago del Estero), predominan los ferrocarrileros. ${ }^{7}$

Respecto a la cantidad de socios, Repetto era cauto, al aclarar que no había podido conocer exactamente el número de afiliados con que contaba cada uno de estos centros. Sin embargo tenía motivos para suponer que ninguno de ellos pasaba de 100 socios. Por último, el dirigente socialista afirmaba que entre los afiliados a los centros de Santiago y de Tucumán "se encuentran algunos maestros de escuela, que no toman parte activa en la propaganda, y la dirección y ejecución de los trabajos está exclusivamente en manos de los trabajadores manuales". 8

Las descripciones de Repetto sobre la composición y el liderazgo de los centros obreros fueron al parecer bastante asertivas, al menos para la fecha en la cual las escribió, es decir al despuntar el novecientos. En efecto, sus comentarios pueden corroborarse con la información proporcionada por otras fuentes, como la obtenida de las publicaciones del anarquismo y en especial del socialismo - condensadas principalmente en La Protesta y La Vanguardia respectivamente $-{ }^{9}$ y los artículos difundidos en la prensa regional y provincial, en particular en diarios como El Orden, de Tucumán. ${ }^{10}$ Asimismo, se relacionan con los datos obtenidos de los censos nacionales y boletines estadísticos, que nos permitieron reconstruir los principales rasgos del universo laboral tucumano. En esa dirección, interesa subrayar que en la medida que la principal producción en Tucumán era el cultivo y la comercialización del azúcar un componente central de la fuerza de trabajo fue el contingente amplio de peones y obreros que laboraban en los establecimientos de azúcar y de alcohol. Al influjo de la especialización azucarera, se desarrolló también, sobre todo en su capital, la ciudad de San Miguel de Tucumán, un amplio y heterogéneo sector de trabajadores de oficio, que incluía albañiles, carpinteros, panaderos, sastres, herreros, fundidores, cocineros, licoreros y hojalateros, entre otros. El desarrollo económico, la modernización y la urbanización alentaron, a su vez, el crecimiento de las ocupaciones vinculadas con el comercio y el transporte (por ejemplo, ferroviarios y cocheros). ${ }^{11}$ Por otra parte, apoyándome en la bibliografía sobre el tema, sabemos que la provincia de Santiago del Estero adquirió una clara configuración agrícola- ganadera después de 1860 y que tras el fracaso de la industria

\footnotetext{
${ }^{7}$ REPETTO, Mi paso por la política..., op. cit., p. 41.

8 Ibid., p. 44.

${ }^{9}$ Creada el 13 de junio de 1897 y tras unos pocos meses de publicarse quincenalmente, en octubre de ese año La Protesta Humana comenzó a editarse como un semanario. Desde noviembre de 1903 se denominó únicamente La Protesta y a partir del 1 de abril de 1904 comenzó a publicarse de forma diaria. Al respecto, se puede consultar Las hojas de la memoria. Un siglo y medio de periodismo obrero y social en la Argentina. In: GONZÁLEZ, Horacio. Idea y coordinación. Buenos Aires: Escuela Talleres Gráficos Manchita, Central de los Trabajadores Argentinos (CTA), Departamento de Cultura, 2000; trabajo que contiene también información sobre La Vanguardia.

${ }^{10}$ El Orden se publicó, salvo los domingos y días festivos, diariamente de forma vespertina (GARCÍA SORIANO, Manuel. El periodismo tucumano: 1817-1900. Ensayo de investigación sobre un aspecto de la cultura de Tucumán durante el siglo XIX. Cuadernos de Humanitas, Tucumá, n. 38, 1972).

${ }^{11}$ AUTOR, 2009, p. 68-69.
} 
azucarera, privada de estímulo oficial, ${ }^{12}$ experimentó el crecimiento de la industria forestal, en consonancia con el incremento de la demanda de durmientes, postes y leña. ${ }^{13}$ En ese contexto, entre otras transformaciones en la estructura socio-profesional, aumentaron las ocupaciones relacionadas con los servicios y se produjo el decaimiento de algunas industrias artesanales. $^{14}$

Son abundantes los testimonios que denunciaban la explotación y la miseria que afectaban a los trabajadores rurales. Así, por ejemplo, los diarios locales y la prensa nacional, especialmente la prensa partidaria, en donde se expresaban los dirigentes obreros del anarquismo y del socialismo, coincidía en impugnar las durísimas condiciones de trabajo a que se veían sometidos los trabajadores por los empresarios y patrones, tanto en los ingenios azucareros como en las explotaciones forestales de Santiago. Paternalismo, crítica y escepticismo se conjugaban en la mirada de dirigentes y militantes anarquistas y socialistas al describir las conductas y hábitos de los obreros del norte del país y de sus posibilidades para encarar las labores de propaganda y de lucha. Con ciertos matices, estos grupos coincidían en sus valoraciones acerca de los trabajadores, en particular los del campo, como individuos ignorantes y poco preparados para la organización gremial y la protesta obrera. Una muestra en ese sentido se reflejó en las consideraciones de Adrián Patroni, quien como sugiere Santiago Bilbao - transitó desde una cierta benevolencia hacia la descalificación completa, al impugnar la capacidad del obrero de la región para protagonizar las luchas obreras contra la explotación de la que eran objeto. En ese sentido, conviene apuntar que el dirigente obrero Patroni visitó en varias ocasiones Tucumán y Santiago del Estero. Con lo cual, pudo participar activamente en el repertorio de actividades de cultura, propaganda y protesta encabezadas por los centros obreros de la región al despuntar el novecientos, tal como veremos un poco más adelante en este trabajo. ${ }^{15}$

Ya había señalado Repetto que los peones del campo eran "el grupo más numeroso, miserable y explotado". Además, afirmaba que eran "ignorantes y supersticiosos, víctimas del alcohol, del juego y de otros vicios", descripción que involucraba a los trabajadores rurales de las principales actividades económicas de cada provincia (Repetto se refería a los individuos ocupados en las tareas de la zafra, en Tucumán, y a las labores del desmonte de bosques, en Santiago). ${ }^{16}$

Respecto a las calificaciones que pesaban sobre otros segmentos del mundo del trabajo, como el de los trabajadores de oficio, es interesante subrayar la ambivalencia de las consideraciones, ya que por un lado se les adjudicaban conductas desfavorables, tales como

\footnotetext{
12 ALÉN LASCANO, Luis C. Desarrollo histórico socioeconómico de la provincia de Santiago del Estero. Departamento de Sociología de la Fundación Bariloche (Inédito).

13 TENTI, María Mercedes. Estratificación social y elites regionales. Proyectos modernizadores y elites regionales la consolidación del estado santiagueño (1903-1916). Trabajo y Sociedad, Santiago del Estero, n. 14, 2010.

14 TASSO, Alberto, "Oficios y profesiones en el mercado de Trabajo de Santiago del Estero (Argentina), entre 1869 1914, Trabajo y Sociedad, Santiago del Estero, n. 1, vol. 1, junio-Setiembre 1999.

${ }^{15}$ BILBAO, Santiago. Adrián Patroni: el presente y el pasado del criollo. Estudios del Trabajo, n. 28, juliodiciembre de 2004, p. 123

${ }^{16}$ REPETTO, Mi paso por la política..., op. cit., p. 41.
} 
la poca instrucción, la incapacidad de ahorro, la propensión a la bebida y al juego, pero también se reconocían a estos trabajadores comportamientos positivos, como su interés por participar en la vida política y la vestimenta decente. Ejemplo de lo anterior fue en Tucumán el trabajo premiado "Medios prácticos para mejorar la situación de las clases obreras" de Julio P. Ávila, quien al despuntar el siglo XX afirmaba:

\begin{abstract}
Nuestro artesano no es instruido, es una desgracia, pero preciso es decirlo, muchos son hasta analfabetos, más tampoco asombra el hecho de encontrar individuos de la clase obrera que escriben con corrección y que demuestran tener una clara inteligencia.

Es sociable y viste, por lo común con decente sencillez. Invariablemente está afiliado a un partido político, tanto que sería difícil encontrar un artesano que haya permanecido neutral en nuestras cuestiones internas, pero pocas veces ejerce con conciencia y espontaneidad sus derechos de ciudadano.

No economiza jamás con la intención de labrarse un porvenir y una vida independiente, por lo que nuestro artesano vive y muere en la miseria.

El vicio de la embriaguez está profundamente arraigado en ellos y cuantos esfuerzos hace la policía para contenerlo resultan ineficaces; el día festivo, para el artesano, es el día destinado a sus diversiones ilícitas, a las riñas de gallos, a los juegos prohibidos, todo precedido y seguido de grandes excesos en el uso de bebidas, casi siempre antihigiénicas por su venenosa composición química. ${ }^{17}$
\end{abstract}

Hábitos asociados a la bebida, el gusto por las diversiones "ilícitas", como las riñas de gallo y los juegos prohibidos, combinados con el entusiasmo por la política, caracterizaron también a los artesanos de Santiago del Estero, de acuerdo a las expresiones vertidas en algunas fuentes, como las imágenes plasmadas en la prensa. Así, en un artículo conmemorativo que recordaba las costumbres en el barrio santiagueño de Cantarranas, el diario más importante de la provincia, El Liberal, subrayaba entre los rasgos característicos de los habitantes de esa zona en torno del 1900 el entusiasmo político y el fervor religioso. ${ }^{18}$

Por supuesto, estos testimonios sobre los trabajadores estaban sesgados por los prejuicios, miedos y descalificaciones que poblaban las miradas de intelectuales, políticos, filántropos y profesionales. Sin embargo, es precisamente a través de los documentos producidos por otros sectores sociales - por ejemplo informes y estudios sobre las clases trabajadoras como el que mencionamos anteriormente - que podemos intentar reconstruir las prácticas, costumbres y tradiciones de los trabajadores. ${ }^{19}$ Teniendo en cuentas los sesgos propios de este tipo de fuentes, quisiera avanzar algunas cuestiones. Aunque los trabajadores de oficio no escaparon a las perjudiciales condiciones de vida que afectaron al conjunto de la clase trabajadora durante la época analizada, expresadas por ejemplo en el hacinamiento habitacional y la falta total de servicios públicos, ${ }^{20}$ al contar con condiciones

\footnotetext{
${ }^{17}$ CAMPI, Daniel; Julio P. Ávila. Medios prácticos para mejorar la situación de las clases obreras, 1892. Comentario, Estudios del Trabajo, Buenos Aires, n. 30, p. 123-146, julio-diciembre de 2005.

${ }^{18}$ Cantarranas. La ciudad lo aprieta hacia el oeste pero no logra borrarlo del recuerdo. El Liberal, Número del Cincuentenario, 1898- 3 de noviembre de 1948, Santiago del Estero, p. 357- 360.

${ }^{19}$ CAMPI, Daniel. Los ingenios del Norte: un mundo de contrastes", en Fernando Devoto y Marta Madero (dir.). Historia de la vida privada en la Argentina. T. II, Buenos Aires: Taurus, 1999, p. 190.

${ }^{20}$ AUTOR, 2009, p. 69.
} 
de trabajo más favorables y mejores retribuciones que otros grupos, como el peones y jornaleros - tal como ya lo indicaba Repetto - aportaron el principal contingente de asociados de los centros obreros en Tucumán y Santiago del Estero. A ellos iba dirigida principalmente la propaganda socialista, interesada en atraer nuevos socios, construir una militancia entre los trabajadores $y$, en definitiva, favorecer la transformación social. Del posible impacto de esta propuesta me ocuparé un poco más adelante en este mismo trabajo. En este momento y apoyándome en la información obtenida mayoritariamente de la prensa, quisiera detenerme, aunque sea brevemente, en la creación, los integrantes y los propósitos que guiaron la vida de los centros obreros.

\subsection{EL CENTRO COSMOPOLITA DE TRABAJADORES DE TUCUMÁN. EL CENTRO SOCIALISTA}

Una lectura de la prensa reveló que el Centro Cosmopolita de Trabajadores fundado en noviembre de 1897 en la ciudad de San Miguel de Tucumán, capital y centro administrativo-comercial de la provincia, integró a trabajadores, en su mayoría de oficio, como tipógrafos, panaderos, sastres, zapateros, carpinteros, cocheros, etc., quienes se constituyeron gradualmente en gremios, en consonancia con la difusión del anarquismo y sobre todo el socialismo, movimiento que desempeñó un papel destacado en la vida de este espacio obrero. ${ }^{21}$ Además de artesanos, el centro cosmopolita se conformó con algunos comerciantes y profesionales. $Y$ tanto en este grupo como en el sector mayoritario del centro compuesto por trabajadores de oficio, la nacionalidad podía ser argentina y extranjera; de ahí la denominación "cosmopolita" que acompañaba al centro.

En cuanto a sus líderes, interesa anotar que, de forma semejante a lo que sucedía en diferentes urbes de Argentina y de otros países latinoamericanos, era frecuente que éstos contaran con una cierta trayectoria en el mundo laboral y público derivada de su participación en prácticas de asociación y de cultura ampliamente valoradas en la época, como las actividades vinculadas con la fundación y/o la edición de un periódico, y las tareas referidas a la organización y la dirección de sociedades, mayoritariamente, mutuales. ${ }^{22}$ En esa tónica, podemos mencionar los casos de los artesanos Juan Sandoval y Daniel López que integraron la comisión directiva del Centro Cosmopolita de Trabajadores y se desempeñaron como dirigentes de otras asociaciones: Sandoval como secretario general de la Sociedad de Obreros Sastres y López como uno de los dirigentes de la Sociedad Unión Tipográfica. También, hubo quienes además de liderar gremios o mutuales, participaron como editores y redactores de periódicos obreros. Tal fue el caso de Daniel Villagrán, quien ocupó la comisión directiva de la asociación de los tipógrafos e intervino activamente en la redacción

\footnotetext{
${ }^{21}$ La Vanguardia, 11/12/1897. Noticias sobre la creación del Centro Cosmopolita de Trabajadores también en El Orden, 3/11/1897 y 28/11/1898 al 19/11/1898.

${ }^{22}$ Esta consideración es planteada por Carlos Illades en su análisis sobre las sociedades de trabajadores en México. ILLADES, Carlos, Hacia la República del Trabajo, La organización artesanal en la ciudad de México, 1853-1876, México: UAM-Iztapalapa/El Colegio de México, 1996, p. 102.
} 
de El Eco del Obrero, órgano de expresión fundado por dicha asociación. ${ }^{23}$ Finalmente, Horacio Raimondi, socialista de origen italiano y figura paradigmática del movimiento asociativo tucumano ocupó la presidencia del Centro Cosmopolita de Trabajadores en 1900 y al año siguiente fue elegido presidente de una de las sociedades étnicas de socorros mutuos más antiguas y conocidas de la provincia, la Sociedad Italiana de Unión y Socorros Mutuos.

Conformado como una sociedad de "protección mutua" bajo el slogan de "Uno para todos y todos para uno", el Centro Cosmopolita de Trabajadores explicaba en una carta dirigida a los centros socialistas y sociedades obreras de Buenos Aires (la cual fue reproducida por el órgano de expresión oficial del socialismo, La Vanguardia, en junio de 1898) que su propósito era defender "la causa del proletariado, es decir el mejoramiento de la clase trabajadora, sosteniendo los ideales cuyo triunfo ustedes persiguen". ${ }^{24}$

Para 1901 no hay ninguna duda de la vinculación del centro tucumano con el Partido Socialista (en adelante PS) en Argentina que lo sitúa como una de las asociaciones del interior del país adheridas a sus filas. ${ }^{25}$

Creado en 1895, el PS se había distanciado - señala Juan Carlos Torres - de la postura antipolítica dominante en el mundo del trabajo y postulado un programa de reformas sociales. Como sostiene el autor,

\begin{abstract}
Para abogar por ellas, sus dirigentes tomaron una decisión estratégica: concurrir a las elecciones. En la visión del PS, los ideales del socialismo en la Argentina tenían por delante una larga marcha hasta que la modernización capitalista se desplegara plenamente e hiciera emerger, corriendo el velo de viejas prácticas políticas y sociales, el conflicto de clases. Con esa creencia en el curso evolutivo de la historia, los socialistas vieron las tribunas electorales como plataformas que podían ser aprovechadas para difundir su mensaje y llamar a los trabajadores inmigrantes a que se nacionalizaran y engrosaran sus filas. ${ }^{26}$
\end{abstract}

Desde esa óptica, podemos leer la importancia otorgada por el Centro Cosmopolita de Trabajadores a la participación política. Una muestra en ese sentido se reveló, por ejemplo, en las elecciones municipales de marzo de 1901, cuando en articulación con otras sociedades el centro presentó un programa y una lista de candidatos para acceder al Consejo Deliberante. ${ }^{27}$

Además, el interés del centro cosmopolita por la política se expresó en las conferencias sobre temas relacionados con la Constitución, la importancia de la vida

\footnotetext{
${ }^{23}$ Referencias sobre El Eco del Obrero se pueden ver, por ejemplo, en El Orden, 4/3/1903. También Daniel Villagrán se desempeñó como secretario de la Sociedad Argentina de Socorros Mutuos de Obreros y fue uno de los redactores de La llustración Obrera. Periódico literario de la juventud obrera, de literatura, artes e intereses generales, fuente sobre la cual hasta ahora no se tenía ninguna noticia y en la cual colaboraban reconocidos integrantes de la Sociedad Argentina de S.M. de Obreros. AUTOR, 2011c.

${ }^{24}$ La Vanguardia, 11/12/1897 y 18/06/1898.

${ }^{25}$ La Vanguardia, 5/1/1901 y 19/1/1901.

26 TORRES, Juan Carlos. ¿Por qué no existió un fuerte movimiento obrero socialista en la Argentina? Entrepasados - Revista de Historia, Buenos Aires, n. 35, p. 151- 163, comienzos de 2009.

${ }^{27}$ El Orden, 9/03/1901, 12/03/1901 y 29/03/1901.
} 
republicana y el sufragio, en las cuales los líderes obreros locales y nacionales insistían en la importancia de intervenir en la arena electoral, exhortando a los trabajadores a registrarse en los padrones cívicos y votar. ${ }^{28}$

Como sostiene un estudioso sobre el tema, Ricardo Falcón, la importancia creciente otorgada por el PS al accionar político, entendido fundamentalmente como "la acción legislativa parlamentaria", ${ }^{29}$ caracterizó a esta fuerza política en el país, contribuyendo a la consideración como un partido reformista. ${ }^{30}$

Paralelamente, el socialismo en el país apoyó la acción sindical, entendida como otra vía apropiada para luchar por mejoras económicas y sociales para los trabajadores. Y, como propone Ricardo Falcón, fue en este terreno de la lucha gremial en donde los socialistas debieron enfrentar a sus más serios competidores: los anarquistas "organizadores", que a fines del siglo XIX "comenzaban a conquistar posiciones significativas en el seno del movimiento obrero, al tiempo que iban extendiendo su influencia hacia otros sectores". ${ }^{31}$

En efecto, el Centro Cosmopolita de Trabajadores desempeñó un papel clave en las protestas de los trabajadores, al respaldar sus movilizaciones para alcanzar mejores condiciones de vida y de trabajo. En esa dirección, apoyó y promovió las demandas orientadas a conseguir el establecimiento del descanso dominical, el aumento del salario y la reducción del horario de trabajo, en especial la sanción de la jornada de 8 horas. También, el centro fomentó las demostraciones de solidaridad obrera, al instar a los gremios tucumanos a pronunciarse públicamente a favor de las manifestaciones y los mítines - ya sea para obtener la sanción de una legislación sobre accidentes de trabajo, o exhibir el repudio a la agresión y represión policial, etc. - que realizaban los trabajadores en Buenos Aires, Rosario y otras ciudades argentinas. ${ }^{32}$

De acuerdo a la documentación consultada, sabemos que, al menos para el año 1904, el centro albergó a militantes anarquistas, quienes - no exentos de conflictos y tensiones - convivieron con los socialistas. Uno de los enfrentamientos más notorios se

\footnotetext{
${ }^{28}$ El Orden, 9/11/1900, 10/11/1900, 12/11/1900 y 01/12/1900.

${ }^{29}$ Como propone un estudioso sobre el tema, Ricardo Falcón, "en la primera década del nuevo siglo la política de los socialistas ya había adquirido un perfil definido: se trataba de la construcción de un partido basado en una doble estrategia hacia el socialismo. Por un lado, se presentaba como un instrumento apto para la consecución de mejoras económicas y sociales para los trabajadores y por otro, como un partido de reformas democráticas, republicanas, "profundas". El nexo entre ambos aspectos era, lo que en la época se llamaba "acción política" y que esencialmente se traducía en la acción legislativa parlamentaria. Ambos aspectos, formaban parte del "programa mínimo" en camino hacia la imposición del socialismo. Camino que presentaba un carácter fundamentalmente evolutivo", FALCÓN, Ricardo. Izquierdas, régimen político, cuestión étnica y cuestión social en Argentina (1890-1912). Estudios Sociales, Santa Fe, año XXI, N o 40, p. 193-221, primer semestre 2011. Artículo publicado originalmente en Anuario de la Escuela de Historia, n. 12, Rosario, 19861987.

${ }^{30}$ Seguimos también a Falcón, quien señala que "en sus orígenes el PS no excluía el recurso a una acción revolucionaria para la conquista del socialismo, aunque ésta debía ser precedida de la 'acción política'. Recién, en el segundo congreso, en 1898, Juan B. Justo lograría suprimir el párrafo final de la declaración adoptada en 1896, imponiendo así definitivamente, lo que sus opositores de entonces llamaban 'reformismo'" (FALCÓN, Izquierdas, régimen político, cuestión étnica..., op. cit., p. 199).

${ }^{31}$ FALCÓN, Izquierdas, régimen político, cuestión étnica..., op. cit., p. 200.

${ }^{32}$ La lucha por obtener el descanso dominical fue analizada especialmente en AUTOR, 2011d y 2011 e.
} 
desencadenó en ese mismo año, a raíz de desacuerdos por el manejo de los fondos económicos, disputa que produjo finalmente el alejamiento de los militantes del anarquismo y probablemente impactó en la vida institucional del centro que después de febrero de 1905 al parecer dejó de existir. ${ }^{33}$

Todo indica que el Centro Cosmopolita de Trabajadores fue sustituido por el Centro Socialista, formado en Tucumán en agosto de $1904 .{ }^{34}$ Adherido también al PS, este nuevo centro desempeñó las mismas tareas que el cosmopolita en la vida de los trabajadores, al favorecer la formación de sociedades obreras, apoyar la lucha gremial y participar en la arena política. ${ }^{35}$ Sin embargo, su denominación trasluce evidentemente una mayor identificación con la fuerza política socialista. Asimismo, en este nuevo espacio ya no participaban los anarquistas.

\title{
1.2. LOS CENTROS SOCIALISTAS EN SANTIAGO DEL ESTERO
}

En agosto de 1898 se creó el Centro Socialista de Santiago del Estero, espacio integrado por trabajadores, mayoritariamente de oficio, y conducido por inmigrantes y nativos de la provincia que simpatizaban con las ideas del socialismo. En ese sentido, resulta conveniente apuntar que a diferencia de lo observado en el análisis del Centro Cosmopolita de Trabajadores de Tucumán no contamos con evidencias acerca de la participación de anarquistas en la vida del Centro Socialista de Santiago del Estero, cuya misma denominación testimonia su filiación explícita con el PS.

Pedro Piergiovanni, Holger Machepremg, Rómulo Rava y Ramón Castillo fueron algunos de los nombres más sonados en las actuaciones de este centro obrero, que reveló desde sus comienzos un manifiesto compromiso con el socialismo, tal como se reflejaba en los discursos impartidos por sus dirigentes y en la lectura de los principios y el programa del PS durante varias de sus veladas. Una muestra en ese sentido se manifestó en la fiesta de inauguración del centro, en donde el dirigente Rómulo Rava

\begin{abstract}
abrió el acto explicando a los presentes las razones generales que impulsan a los trabajadores a buscar en la organización del partido de clase el arma más poderosa para luchar en defensa de los intereses políticos y económicos que directamente atañen al proletariado. Explicó después de leer la Declaración de Principios y Programa del Partido, la imperiosa necesidad de que los asalariados de Santiago imitaran a los compañeros de todas las partes adhiriéndose al nuevo centro. ${ }^{36}$
\end{abstract}

\footnotetext{
${ }^{33}$ Agradezco a María Cristina Tortti su sugerencia de tomar en cuenta, además, que durante esa época se efectuó la primera gran escisión del Partido Socialista, con la salida de los anarcosindicalistas. Es probable entonces que este proceso impactara en los enfrentamientos entre socialistas y anarquistas en el Centro Cosmopolita de Trabajadores de Tucumán, causando el alejamiento de los anarquistas y poco después la disolución de este espacio.

${ }^{34}$ El Orden, 18/8/1904 y La Vanguardia, 27/8/1905.

${ }^{35}$ El Orden, 18/8/1904 al 4/5/1910. Sobre la adhesión del centro al Partido Socialista véase también el Libro de Actas del Comité Electoral Central, en IÑIGO CARRERAS, Nicolás. Presentación. In: Documentos para la historia del partido socialista, Buenos Aires, Instituto de Estudios Históricos-Sociales “Prof. Juan C. Grosso”, 1996.

${ }^{36}$ La Vanguardia, 31/12/1898.
} 
Otra asociación socialista que se formó en la provincia de Santiago del Estero durante el periodo estudiado fue el centro obrero de Frías, espacio estrechamente relacionado con la empresa de ferrocarriles. Así, y tal como informaba a comienzos de 1901 La Vanguardia, dentro de las agrupaciones del norte del país adheridas al Partido Socialista Argentino figuraban el Centro Cosmopolita de Trabajadores de Tucumán, el Centro Socialista de Santiago del Estero y el Centro Socialista de Frías. ${ }^{37}$

Al año siguiente, en 1902, en el marco de una de las visitas a la provincia del conocido propagandista y militante del socialismo, Adrián Patroni, se constituyó un centro socialista en La Banda. ${ }^{38} \mathrm{~A}$ los fines de esta investigación, resulta importante subrayar la difusión que alcanzó el socialismo en La Banda - "localidad con importante dinamismo económico en la época, como efecto del desarrollo ferroviario" - reflejado en numerosas actividades de educación, cultura, recreación y protesta. El ejemplo más contundente en ese sentido fue la creación de una escuela laica, dependiente del centro socialista, que llegó a reunir más de 70 alumnos y se erigió en una de las experiencias educativas más destacadas del socialismo en el país; ${ }^{39}$ más adelante en este trabajo volveremos sobre esta iniciativa.

Para terminar, interesa anotar que, de forma similar que el Centro Cosmopolita de Trabajadores y posteriormente el Centro Socialista de Tucumán, los centros socialistas de Santiago del Estero se ocuparon de las problemáticas concernientes a la vida política, especialmente en el terreno electoral. Para ello, recurrieron a diversas estrategias, entre las cuales podemos mencionar las conferencias y los discursos pronunciados por los dirigentes obreros, quienes incentivaban a los asociados a inscribirse en los registros cívicos y a votar. Una muestra clara del interés de los centros socialistas por fomentar las expresiones políticas de los trabajadores se reveló claramente en la asamblea celebrada por el Centro Socialista de Santiago del Estero en noviembre de 1902 que resolvió "incitar a todos sus afiliados con derechos políticos, a inscribirse en los Registros Cívicos, Nacional y Provincial, y también invitar a los ciudadanos independientes a verificar este acto, demostrándoles que la abstención, servía a la impunidad de la oligarquía predominante". Y tal como informaba el centro, el resultado conseguido con su prédica había sido bastante favorable, ya que las mesas funcionaron con regularidad. ${ }^{40}$

Tiene sentido pensar que la importancia otorgada por el PS a la participación política en la arena electoral inspiró estas expresiones de los trabajadores en Santiago. Además, y relacionado con el valor asignado por el socialismo a la protesta obrera, los centros socialistas de Santiago del Estero apoyaron las demandas de los trabajadores para obtener la jornada de 8 horas y el incremento de los salarios, reclamos centrales del movimiento obrero, respaldaron las manifestaciones en favor de una legislación sobre accidentes de trabajo y se sumaron al repudio a medidas represivas como la Ley de Residencia, en

\footnotetext{
${ }^{37}$ La Vanguardia, 5/1/1901, 19/1/1901 y 26/01/1901.

${ }^{38}$ La Vanguardia, 26/07/1902.

${ }^{39}$ BECERRA, Marina. ¿Fiestas patrias o fiestas socialistas? Rituales escolares e identidad socialista a principios del siglo XX. In: CAMARERO, Hernán; HERRERA, Carlos Miguel. El partido socialista en Argentina: sociedad, política a ideas a través de un siglo. Buenos Aires: Prometeo, 2005, p. 97- 119.

${ }^{40}$ La Vanguardia, 22/11/1902.
} 
solidaridad con las movilizaciones de Buenos Aires, Rosario y otras urbes de Argentina. ${ }^{41}$

\section{LAS CONMEMORACIONES Y FESTIVALES OBREROS}

Un aspecto primordial de las iniciativas desplegadas por los centros de trabajadores de Tucumán y de Santiago del Estero fueron las veladas y tertulias literario-musicales que buscaban combinar los fines de recreo con los orientados a fomentar la construcción de una militancia e identidad obrera. Tales fiestas reproducían un programa previamente establecido que incluía, mayoritariamente, discursos y conferencias pronunciadas por dirigentes locales o nacionales sobre temas típicos de la época y/o problemáticas que podían interesar a los trabajadores, como cuestión social, influencia de la ciencia, emancipación de la mujer y difusión del socialismo. Además, en dichas celebraciones se entonaban himnos revolucionarios, se recitaban poesías y se representaban obras de teatro caracterizadas por su contenido social y contestatario. Estos números culturales y artísticos se completaban con los destinados específicamente al entretenimiento como rifas y, especialmente, bailes. ${ }^{42}$

En estudios anteriores analizamos las veladas y tertulias literario-musicales, conocidas también como "festivales obreros de propaganda", organizadas en Tucumán por el Centro Cosmopolita de Trabajadores y posteriormente por el Centro Socialista. Como señalábamos entonces, dichos festejos articulaban por lo general conferencias sobre temas de actualidad e interés obrero y/o palabras alusivas pronunciadas por algún líder del centro o un dirigente obrero invitado, con la participación de orquestas y coros que entonaban himnos revolucionarios, conjuntos filo-dramáticos que presentaban algún drama social y niñas que declamaban poesías. Además, las veladas podían incluir entretenimientos como sorteos y finalmente un baile, probablemente uno de los momentos más atractivos y esperados de la fiesta. ${ }^{43}$

Con el interés de avanzar en esta temática, en este trabajo indagamos las prácticas desplegadas por los centros socialistas localizados en Santiago del Estero. De acuerdo a lo que se reveló en las fuentes, las fiestas recorrían un itinerario semejante a lo detectado para Tucumán. Así, y tal como era lo usual en los festejos del socialismo, los himnos obreros principalmente el "Himno de los trabajadores" e "Hijos del Pueblo" -, las declamaciones poéticas, las piezas teatrales, los discursos y las conferencias dictadas por dirigentes obreros, combinadas con alguna rifa y finalmente un "baile de recreo" formaron parte central de las fiestas. $^{44}$

Sin embargo, a diferencia de las veladas tucumanas, las organizadas en Santiago podían incluir la lectura del "Programa Mínimo" del PS como parte de los números

\footnotetext{
${ }^{41}$ Por ejemplo, el Centro Socialista de Santiago del Estero resolvió en asamblea del 22 de diciembre de 1903 adherirse al meeting de protesta [en Buenos Aires contra la Ley de Residencia] y celebrar al efecto una reunión pública en su local social. La Vanguardia, 17/01/1903.

${ }^{42}$ Al respecto, resultaron especialmente iluminadores los trabajos de SURIANO, Cultura y política..., op. cit. y MASES, El tiempo libre..., op. cit.

${ }^{43}$ AUTOR, 2009, 2011a y 2011b.

${ }^{44}$ A modo de ejemplo, La Vanguardia, 31/12/1898, 8/04/1899, 24/05/1902 y 8/10/1903.
} 
presentados. Además, la participación de las mujeres era más notoria en los ámbitos obreros de Santiago que en los tucumanos. Una muestra clara en ese sentido, se reveló por ejemplo en la conferencia realizada en los centros de La Banda en marzo de 1903, donde la esposa del dirigente local Federico Mackeprang, tomó la palabra para explicar la importancia y la necesidad de la asociación entre los trabajadores. Posteriormente, se dirigió al sexo femenino con el propósito de exhortarlas a "abandonar la iglesia y el confesionario y a no creer que al hombre tan ignorante como enemigo del progreso y de la ciencia; y que mejor fuera que enseñaran a sus hijos el amor al trabajo y a sus semejantes". ${ }^{45}$

Es cierto que el accionar femenino se manifestaba sobre todo en su carácter de esposas e hijas de los asociados y se expresaba mayoritariamente a través de declamaciones poéticas. Sin embargo, este papel de las mujeres en los ámbitos obreros del socialismo en Santiago del Estero no debe subestimarse. Por un lado, porque formaba parte de las prácticas socialistas que buscaban atraer a las mujeres a la militancia. Por otro lado, porque rescataba el valor otorgado a la emancipación de la mujer, uno de los tópicos recurrentes de la cultura de la época.

\section{1. ¿CUÁNDO SE ORGANIZABAN LAS FIESTAS?}

Generalmente, tanto los centros de trabajadores de Tucumán como los de Santiago del Estero organizaban sus fiestas para celebrar aniversarios fundamentales de la lucha obrera. Así, por ejemplo, aprovechando las amplias instalaciones de su nuevo local social, el Centro Socialista de Santiago del Estero convocó, en abril de 1899, a una reunión para conmemorar el 26 aniversario de la Comuna de París. En el transcurso del encuentro se escucharon a dirigentes como Rómulo Riva, quien "fustigó enérgicamente a los detractores de la Comuna, pidiendo luego a los compañeros perseverancia en la idea que los anima". Por su parte, Pedro Piergiovanni explicó la Comuna y sus causas, mientras otro dirigente, Vigna, impartió un discurso sobre la fuerza de las minorías. Posteriormente, uno de los socios, el profesor de violín Holger Machepreng ejecutó el "Himno de los trabajadores" y el himno "Hijos del pueblo", finalizando el festejo con una tertulia familiar. ${ }^{46}$

Además de las efemérides caracterizadas del calendario obrero, los trabajadores celebraron acontecimientos destacados que atrajeron la atención de los contemporáneos. Tal fue lo que sucedió, por ejemplo, con el año nuevo de 1901, cuando el Centro Cosmopolita de Trabajadores de Tucumán decidió festejar con un "animadísimo" baile, combinado con números culturales como la declamación de la poesía "Mi bandera", 47 la finalización del siglo XIX y el inicio de una nueva centuria. ${ }^{48}$

Pero también las veladas podían ser convocadas sin mediar un motivo relacionado explícitamente con un suceso primordial concerniente a la lucha obrera o a un momento

\footnotetext{
${ }^{45}$ La Vanguardia, 07/03/1903.

${ }^{46}$ La Vanguardia, 08/04/1899.

${ }^{47}$ La Vanguardia, 12/01/1901.

${ }^{48}$ La Vanguardia, 12/01/1901.
} 
sobresaliente del calendario universal, lo cual no significaba que las fiestas dejaran de asignar un lugar relevante a la instrucción y la difusión de repertorios de la cultura obrera. Esto era así porque las veladas servían no sólo para otorgar un espacio específico al disfrute del tiempo libre de los trabajadores sino, también, para moldearlo dentro de los contornos de las aspiraciones de los dirigentes, interesados en fomentar la conformación y el desarrollo de una militancia obrera, de acuerdo a los parámetros del anarquismo y especialmente del socialismo, movimiento que sobresalió en las actuaciones de estos espacios obreros en el norte argentino.

En esos parámetros, podemos situar la conferencia y el baile que tuvo lugar el 2 de setiembre de 1903 en el centro socialista de Santiago, en donde "ante bastante concurrencia y bien representado el sexo femenino, el compañero $H$. Raimondi disertó en italiano, historiando a grandes rasgos los hechos que precedieron a la caída del poder temporal de los papas, la participación activa que tuvo en ella la clase laboriosa, y su incesante lucha hacia el completo triunfo del socialismo, con la caída de todas las supremacías, injusticias, dogmas y prejuicios". El evento incluyó la representación de la comedia "Futuras propagandistas", a cargo de un grupo de niñas y la participación de la orquesta que tocó el Himno de Turati y otras piezas musicales. ${ }^{49}$

Me interesa sugerir dos cuestiones que se desprenden de esta fiesta. La primera, se refiere a los vínculos asociativos entre el Centro Socialista de Santiago del Estero y el Centro Cosmopolita de Trabajadores de Tucumán, expresado, por ejemplo, en la disertación de Horacio Raimondi, quien como ya lo hemos señalado en el trabajo, participó de la conducción del centro cosmopolita. La segunda se relaciona con los objetivos de las fiestas que invariablemente articulaban los fines recreativos con los destinados a estimular la construcción, el fortalecimiento y la difusión de identidades obreras según los principios socialistas.

\subsection{LA "FIESTA DEL TRABAJO"}

Ahora bien, ningún acontecimiento resultaba más propicio para unir los propósitos de recreación, cultura y propaganda que el 10 de mayo o Fiesta del Trabajo, sin duda la principal conmemoración obrera. Año tras año, los centros tucumanos -el Centro Cosmopolita de Trabajadores y posteriormente el Centro Socialista- y los centros socialistas de Santiago del Estero, La Banda y Frías impulsaron actividades para recordar dicha efeméride. Generalmente, las conmoraciones incluían una primera etapa caracterizada por una manifestación en los espacios públicos, en donde algún renombrado personaje del mundo obrero dirigía la palabra a los trabajadores, y un segundo momento en el cual el festejo se realizaba en el local del centro.

Veamos algunas de estas prácticas. En 1902 el Centro Socialista de Santiago del Estero, decidido a "festejar dignamente" la Fiesta del Trabajo, solicitó al comité ejecutivo del PS el envío de un delegado para participar de los actos de ese día. Asimismo, pidió a los

\footnotetext{
${ }^{49}$ La Vanguardia, 08/10/1903.
} 
centros del norte del país que quisieran cooperar con la gira de propaganda del delegado que se pusieran en comunicación con el centro con el fin de acordar la manera más conveniente para todos de sufragar los gastos de viaje. Quien llegó a la provincia enviado por el PS fue nada menos que el dirigente obrero Adrián Patroni, quien desempeñó, como ya lo habíamos señalado antes en este trabajo, un lugar protagónico en las actuaciones de los trabajadores en el norte argentino durante el periodo estudiado.

Según los relatos difundidos en La Vanguardia, la fiesta del 1으 de mayo adquirió contornos ampliamente positivos.

\begin{abstract}
Preparados con anticipación todos los elementos necesarios para el mejor resultado de la manifestación del 1 으 de mayo al despuntar el alba de este día varias bombas saludaron la fiesta del trabajo. Un numeroso grupo de compañeros fueron a recibir al delegado Patroni encaminándose luego al correo donde dirigieron telegramas de felicitación a varios puntos de la república. En la plaza principal se improvisó una tribuna y el compañero Rava después de leer el Programa Mínimo del partido presentó al compañero Patroni el cual ante una concurrencia de 300 personas explicó el significado del 10 de mayo y dijo que los trabajadores debían ser perseverantes en la lucha, entusiasmando a los presentes que aplaudían las palabras del orador. ${ }^{50}$
\end{abstract}

Tras la reunión pública en la plaza, que incluyó la lectura del Programa Mínimo del partido, una explicación del 1o de mayo y la exhortación a los trabajadores para que perseveraran en su lucha, los festejos continuaron en la noche en el local del centro socialista que, de acuerdo con la descripción de las fuentes, presentaba "un aspecto atrayente"; su proscenio estaba adornado "con una faja roja de la que se destacaban leyendas alusivas al acto". Sin duda, el momento central de la celebración fue la conferencia impartida por Patroni sobre el tema: el socialismo y sus causas. ${ }^{51}$

Probablemente, como un modo de aprovechar al máximo la visita de los propagandistas obreros en la provincia, los centros socialitas organizaban actividades culturales durante el tiempo que durase su estadía. Así, el 2 de mayo, al día siguiente de la Fiesta del Trabajo, el Centro Socialista impulsó la conferencia, impartida por Patroni sobre el tema "Democracia cristiana y democracia socialista", en donde -según aseguraba La Vanguardia- el conferenciante "leyó y refutó el libro Manual del Obrero, de P. Monteverde, destruyendo todas sus mentiras y poniendo de relieve la superioridad del socialismo sobre las ideas religiosas, convenciendo al auditorio de que el clero usa un arma traidora y desleal para contrarrestar la marcha triunfal del socialismo científico". Asimismo, el día 3 Patroni dictó una conferencia en el local del centro socialista sobre "El alcoholismo y sus funestas consecuencias" y, finalmente, el 4 de mayo, en compañía de 20 miembros del Centro Socialista de Santiago del Estero, se trasladó a La Banda, localidad en donde "existe la verdadera población obrera". Allí, el dirigente socialista evidenció las causas del estado en que se encontraban los trabajadores; "habló durante una hora y media, fue la mejor conferencia que dio. (Mientras llegaba el tren en que debía partir nos aleccionó en la

\footnotetext{
${ }^{50}$ La Vanguardia, 17/5/1902.

${ }^{51}$ Ibid.
} 
propaganda)", relataba el órgano de prensa oficial del PS. ${ }^{52}$

Por su parte, el Centro Cosmopolita de Trabajadores de Tucumán organizó una velada musical la noche del 10 de mayo de ese año de 1902. Considerada como una de las mejores fiestas del trabajo que había tenido la provincia, sabemos que la celebración estuvo acompañada por la presencia unos días después de Adrián Patroni, quien impartió dos conferencias. La primera, la dictó el lunes en la sede del centro cosmopolita sobre "la razón de ser del socialismo" y la organización de los obreros, en donde expuso "con sencillez y erudición las ideas sociales y sobre todo criticó la desidia del obrero que a pesar de ser el único que produce no advierte que vive manteniendo parásitos y zánganos", según narraba La Vanguardia. ${ }^{53}$ En la segunda charla, realizada en un espacio más amplio como era el local de la Sociedad Española, una de las primeras sociedades de ayuda mutua creadas en Tucumán, Patroni abordó frente a un público calculado por el semanario socialista en no menos de 1000 personas el tema "Democracia cristiana y socialismo". La controversia que sostuvo el conferenciante con dos sacerdotes, en una larga y ardua discusión, sumado al significativo número de asistentes a la conferencia, probablemente debido al interés generado por la temática abordada en la misma, llevaron a esta fuente a calificar a la reunión como "el acto público más trascendental realizado en Tucumán". ${ }^{54}$

En síntesis, los temas abordados en discursos, disertaciones, poesías y canciones durante la celebración del 10 de mayo revelaban la importancia que revestía este aniversario dentro del repertorio de prácticas obreras. Tal como se entendía en la época, la Fiesta del trabajo debía contribuir a impulsar y fortalecer las demandas de los trabajadores para conseguir mejores condiciones de vida y de trabajo. En última instancia, esta efeméride tenía que favorecer el tránsito hacia una sociedad más justa e igualitaria, de acuerdo con las premisas del socialismo, movimiento que lideró las actividades de los centros de trabajadores en Tucumán y Santiago del Estero.

Por otro lado, la celebración del 1ㅇ de mayo, así como el conjunto de conferencias impartidas durante los días siguientes, evidenciaron una característica recurrente de las prácticas obreras: la visita de conocidos líderes socialistas constituía un momento esencial de la vida de los centros de trabajadores que fomentaba numerosas actividades de sociabilidad, propaganda y cultura, principalmente conferencias. Lo cual, sin duda, no resulta extraño en la medida que se trataba de renombrados dirigentes del socialismo que realizaban giras de propaganda obrera para construir y fortalecer la militancia en el país.

En esa tónica, también, podemos situar los festejos del 1으 de mayo organizados por el Centro Socialista de Santiago del Estero en 1903 que contaron con la participación de Bernardo Irurzun, enviado como delegado del PS. Luego de ser recibido en la estación de trenes, al despuntar el día 1 o de mayo, Irurzun habló ante una tribuna formada en el principal paseo público de Santiago, la Plaza Libertad, a las 10 de la mañana. Allí, frente a una concurrencia estimada en aproximadamente 250-300 personas, según cálculos de la prensa

\footnotetext{
52 Ibid.

${ }^{53}$ La Vanguardia, 10/5/1902.

${ }^{54}$ Ibid. Noticias sobre estas conferencias también en El Orden, 06/05/1902 y 07/05/1902.
} 
partidaria, el delegado socialista amplió lo dicho en su discurso de apertura por el dirigente local Ernesto L. Abalos sobre el valor de la fiesta del trabajo. Además, explicó el significado de la jornada de 8 horas y la necesidad de su ejecución; cuestionó a la institución militarista "con sus oprobiosas vergüenzas" e impugnó la Ley de Residencia, "demostrando con ese ejemplo las medidas represivas a que llegan los burgueses cuando peligran sus bolsillos". ${ }^{55}$

De esta forma, Irurzun se refería a temas comunes de la época y a tópicos centrales del socialismo y del movimiento obrero durante el periodo bajo estudio, como la jornada de 8 horas, sin duda una de las principales demandas de los trabajadores en Argentina durante la primera década del siglo XX. Otra preocupación presente en el discurso del delegado socialista, la crítica a la institución militarista, remitía a una de las problemáticas más debatidas en ese entonces y frente a la cual los movimientos de izquierda en el mundo del trabajo como el socialismo postulaban, por un lado, la supresión de los ejércitos permanentes $y$, por el otro, el armamento general del pueblo. ${ }^{56}$ Por último, Irurzun rechazaba la Ley de Residencia, una de las medidas más duras dictadas en nuestro país para reprimir a los militantes extranjeros del socialismo y especialmente del anarquismo ante el incremento de la visibilidad y la protesta obrera al despuntar el novecientos.

La programación prevista para conmemorar la Fiesta del Trabajo de 1903 incluía una reunión en el local del Centro Socialista de Santiago del Estero a las 20 horas de ese día 10 de mayo. De acuerdo con los testimonios consultados, podemos señalar que un gran número de concurrentes llenó el "espacioso local" del centro durante dicho festejo, el cual incluyó los discursos pronunciados por militantes y dirigentes locales como Abalos y Mackenpran, las palabras de la militante Petersen sobre la emancipación de la mujer y cantos como "La Jornada de 8 horas". Sin duda, el número principal presentado en esta celebración fue la conferencia dictada por el delegado del PS, Irurzun, sobre "las bases del socialismo, su programa práctico y de inmediata aplicación." ${ }^{57}$

Las actividades continuaron. El domingo en la mañana se realizó un acto en la plaza Libertad en donde hablaron los dirigentes locales Rava y Mackeprang, mientras Irurzun explicó "la absorción de todas las fuentes de riqueza hecha por la clase burguesa apoyada por el clero y el militarismo". ${ }^{58}$

Más tarde, acompañado por un grupo de compañeros del centro socialista, el delegado del socialismo se trasladó a La Banda y ante una numerosa concurrencia reunida en el local del centro obrero disertó sobre el significado del 10 de mayo, la jornada de 8 horas y la necesidad de luchar en el terreno político. Al día siguiente, frente a "una aglomeración de gente jamás visto en esa población" hablaron militantes locales y posteriormente Irurzun abordó tópicos como la Ley de Residencia y se refirió a la necesidad de que "los compañeros extranjeros se naturalicen para contrarrestar en la lucha política los efectos de la tiranía

\footnotetext{
${ }^{55}$ La Vanguardia, 9/5/1903.

${ }^{56}$ Esta posición frente al problema militar se expresó en la plataforma con la que participó, por primera vez, el Partido Socialista en las elecciones para diputados por la capital, en marzo de 1896, tal como sostiene REPETTO, Mi paso por la política..., op. cit., p. 63-64.

${ }^{57}$ Ibid.

${ }^{58}$ Ibid.
} 
capitalista" ${ }^{59}$

Para terminar, la máxima conmemoración obrera, la denominada Fiesta del Trabajo, celebrada cada año los 10 de mayo, podía contribuir a transmitir un ideario de lucha entre los trabajadores, fortalecer sus vínculos asociativos y vigorizar sus lazos con el movimiento socialista. Para ello, los dirigentes y militantes recurrían a los repertorios propios de la cultura obrera - como himnos y cantos revolucionarios, poemas y obras de teatro de contenido social y contestatario. ${ }^{60}$ Además, pronunciaban combativos discursos orientados a recordar sucesos claves del movimiento obrero, subrayar sus demandas centrales, en especial el reclamo de la jornada de 8 horas, y destacar sus principales conquistas. De acuerdo a los objetivos del PS, los líderes obreros insistían a su vez en la necesidad de participar en la arena política, para lo cual era fundamental que los trabajadores extranjeros se naturalizaran. ${ }^{61}$

En esa dirección, las dos fases que observamos en los festejos: por un lado, la manifestación de los trabajadores en los espacios públicos y, por el otro, la reunión en la sede de los centros obreros, funcionaban así como dos momentos complementarios de una misma empresa destinada, en definitiva, a fortalecer y a demostrar el crecimiento del movimiento obrero bajo el liderazgo e influencia de los socialistas.

Otra modalidad implementada por los líderes de los centros para robustecer la confianza de los trabajadores en la asociación y la protesta, acercándolos a su vez a las consignas y los postulados del socialismo, consistió en impulsar una serie de actividades de naturaleza cultural y educativa, como la creación de salones de lectura, bibliotecas y escuelas, temas de los que me ocuparé a continuación.

\section{BIBLIOTECAS Y ESCUELAS}

La construcción de una militancia obrera requería invariablemente instruir y concientizar a los trabajadores en nociones relacionadas, por ejemplo, con el valor de la agremiación, la importancia de la lucha política y la teoría y la práctica del socialismo. Con ese fin los centros organizaron veladas culturales que combinaban los propósitos dirigidos al aprovechamiento del tiempo libre con los objetivos dirigidos a estimular la conformación, el

\footnotetext{
${ }^{59}$ Ibid.

${ }^{60}$ Nos apoyamos en especial en la definición de cultura obrera propuesta por Hernán Camarero en su libro: "una categoría que permite englobar el entramado de prácticas y agencias político-culturales que tenían como protagonistas principales a colectividades de trabajadores; también incluye un conjunto de actitudes, creencias, patrones de comportamiento, imaginarios y rituales, articulados en torno a una identidad obrera, que traslucen una conciencia de clase proletaria. De todos los posibles sentidos implicados en la categoría cultura obrera, aquí se privilegia el que se refiere al desarrollo de formas asociativas y hábitos ligados a la instrucción y a la recreación de los trabajadores", CAMARERO, Hernán. A la conquista de la clase obrera. Los comunistas y el mundo del trabajo en la Argentina, 1920-1935. Buenos Aires: Siglo XXI, 2007, p. 219.

61 Tal como sostiene Falcón, en la época, se entendía "la acción parlamentaria futura como instrumento fundamental para la conquista de reformas democráticas generales y económico-sociales de los trabajadores". Desde esa óptica, el partido socialista realizaba una propaganda para que los trabajadores extranjeros se naturalicen con vistas al ejercicio de los derechos electorales. FALCÓN, Izquierdas, régimen político, cuestión étnica..., op. cit., p. 198.
} 
aprendizaje y la difusión de una identidad y cultura obrera, impregnada por los principios y las prácticas socialistas.

Una faceta central de estas fiestas fueron, como vimos, los discursos y las conferencias, que no sólo tenían lugar durante las veladas sino también en eventos especialmente convocados para tal fin. Impartidas por dirigentes obreros, las disertaciones abordaron un abanico extenso de problemáticas, algunas de las cuales formaban parte del horizonte temático común de la época - cuestión social, alcoholismo, religión, emancipación de la mujer, etc. - y otras concernían específicamente a los movimientos de izquierda en el mundo del trabajo. En esta línea podemos situar a las conferencias que versaban sobre la Comuna de Paris, la jornada de 8 horas, la importancia y la necesidad de la asociación de los trabajadores, la lucha de la clase trabajadora hacia el triunfo del socialismo, la democracia socialista, contrapuesta a la democracia cristiana.

A través de estas disertaciones, que cumplían un papel esencial en las labores de difusión, instrucción y concientización de los trabajadores tal como ha sido señalado por la bibliografía sobre el tema, ${ }^{62}$ los líderes obreros podían transmitir las consignas del PS sobre la importancia de la participación política, particularmente la denominada vía parlamentaria, a tiempo que difundir las premisas acerca de la necesidad de la protesta gremial, entendidas como instancias necesarias para favorecer la transformación social y arribar a una sociedad más justa e igualitaria.

Estrechamente relacionado con la preocupación por educar y convencer a los trabajadores que inspiró la práctica de la conferencias, ${ }^{63}$ los centros obreros asignaron especial importancia a las labores culturales en torno a la construcción y el desarrollo de una biblioteca. ${ }^{64}$ En efecto, uno de los propósitos fundamentales que guiaron las actuaciones de los líderes obreros en Tucumán y Santiago fue la edificación de salones de lectura y de bibliotecas en sus locales. En el caso del Centro Socialista de Santiago del Estero este anhelo estuvo presente desde muy temprana fecha, plasmándose hacia 1899 - un año después de la fundación del centro - en los proyectos de construcción de una biblioteca, cuya formación para mediados de 1901 había avanzado notablemente, al recibir varias donaciones de libros. Al año siguiente, aprovechando el marco de una de las conferencias impartidas por Adrián Patroni, fue formalmente inaugurada la biblioteca popular obrera, la cual para 1903 contaba con más de 600 volúmenes y un significativo y regular movimiento de lectores. ${ }^{65}$ Más dilatados fueron, en cambio, los pasos seguidos por el Centro Cosmopolita de Trabajadores de Tucumán para construir una biblioteca. En 1904, es decir siete años después de su

\footnotetext{
${ }^{62}$ Seguimos a SURIANO, Cultura y política..., op. cit., p. 117-119.

63 Ibid.

${ }^{64}$ Como fue señalado por la bibliografía sobre el tema, las distintas tendencias organizadas del mundo del trabajo, como el socialismo, el anarquismo, el sindicalismo y, posteriormente, el comunismo confluyeron en la valoración brindada a la biblioteca, percibida como una faceta fundamental de las labores culturales emprendidas por los centros obreros. Al respecto, MASES, El tiempo libre..., op. cit., p. 73-97 y GUEREÑA, JeanLouis. Hacia una historia socio-cultural de las clases populares en España (1840-1920). Historia Social, Valencia, n. 11, Otoño 1991, p. 157.

65 La Vanguardia, 15/06/1901, 17/05/1902 y 11/07/1903.
} 
creación, consiguió inaugurar un salón de lectura y avanzaron los proyectos para establecer la biblioteca. ${ }^{66}$

De alguna manera, estas demoras de los centros para concretar la conformación de bibliotecas en sus sedes se reflejaron en los escritos de Repetto, quien en sus comentarios sobre los trabajadores del norte argentino, realizados a partir de su viaje a la región en 1901, aseguraba que si bien los centros de Santiago del Estero y Tucumán disponían de "buenos locales, especialmente el de Santiago" carecían de "lo esencial": la biblioteca.

\begin{abstract}
El Centro de Santiago posee una colección de folletos anárquico socialistas, pero está absolutamente desprovisto de obras de historia, geografía, economía política, etc. Los centros de Tucumán y Frías no disponen ni de ese plantel para una futura biblioteca. La costumbre de celebrar conferencias semanales, ya sea en locales cerrados o en las plazas públicas, no está arraigada en nuestros compañeros de Santiago y Tucumán, ni se observa en ellos ese afán por la lectura que se nota ya en los socialistas bonaerenses. Estas circunstancias determinan cierto estancamiento en la instrucción socialista de nuestros compañeros, que se revela de una manera muy neta por el prestigio de que gozan ciertas declamaciones utópicas de otros tiempos". ${ }^{67}$
\end{abstract}

Además de estos cuestionamientos, Repetto hacía referencia al personalismo que impregnaba diferentes prácticas asociativas en los centros y al excesivo anticlericalismo que, según el dirigente socialista, caracterizaban las actuaciones de los militantes de los centros obreros en Santiago y Tucumán. Y para revertir estar situación, recomendaba a los centros que efectuaran sus trabajos de propaganda siguiendo el objetivo principal de "formar la consciencia de clase y organizar a los trabajadores de los centros urbanos". Proponía que esta propaganda se efectuara a través de "conferencias, libros, periódicos, reuniones públicas, etc. y otorgara especial importancia a difundir "los principios y artículos contenidos en el programa de nuestro Partido, a fin de formar afiliados que posean cierta uniformidad de ideas y de propósitos". ${ }^{6}$

Más allá del sesgo que probablemente impregnó su mirada sobre las características y el funcionamiento de los centros de trabajadores en el norte argentino, reputadas siempre por Repetto en términos de inferioridad con respecto al accionar de "los socialistas bonaerenses", lo que me interesa, en rigor, es sugerir el impacto que probablemente tuvo su visita al norte argentino y, sobre todo, sus exhortaciones a los dirigentes y los socios de los centros obreros. Los trabajos de propaganda obrera, expresados en la puesta en marcha de veladas y tertulias literario-musicales, la organización de conferencias sobre temas de actualidad y de interés obrero y los avances observados en materia de conformación de salones de lectura y biblioteca constituyen, a mi entender, una muestra en ese sentido. Asimismo, los comentarios realizados por militantes locales, plasmados en la prensa socialista, dan cuenta de la influencia que tuvieron las consideraciones de Repetto sobre los

\footnotetext{
${ }^{66}$ El Orden, 18/1/1904. Según afirmaba La Protesta Humana, 26/4/1902, la fundación de un salón de lectura constituyó una propuesta de los miembros anarquistas del Centro Cosmopolita de Trabajadores.

${ }^{67}$ REPETTO, Mi paso por la política..., op. cit., p. 42.

${ }^{68}$ Ibid., p. 47.
} 
trabajadores organizados en Tucumán y Santiago. ${ }^{69}$ Finalmente, la valoración del dirigente socialista acerca del "carácter esencialmente anticlerical" que asumía la propaganda socialista en Santiago y Tucumán reviste especial interés, en la medida que puede vincularse con un dato observado en nuestro análisis. En contraste con otras experiencias de los trabajadores en Argentina durante la misma época, en particular con las prácticas obreras en ciudades como Buenos Aires, donde las disputas más frecuentes eran entre socialistas y anarquistas, en el norte el enfrentamiento característico era el que se entablaba entre socialistas y católicos.

Ahora bien, vinculado con el valor conferido a la lectura y la instrucción, otra consigna clave que se plantearon los centros obreros fue estimular la educación mediante la edificación y el sostenimiento de escuelas. Según la documentación analizada, podemos apuntar que el Centro Cosmopolita de Trabajadores aspiraba a establecer una escuela para niños pobres. ${ }^{70}$ Lamentablemente carecemos de referencias acerca de la materialización de este proyecto, con lo cual es factible pensar que el mismo no logró concretarse.

En contraste, tenemos noticias suficientes sobre las experiencias educativas de los centros socialistas en Santiago del Estero, en particular, del centro obrero de La Banda, bajo cuyos auspicios funcionaban dos establecimientos: la escuela mixta y la escuela nocturna para varones, a las cuales me referí brevemente en la primera sección del trabajo. Debido a la influencia que alcanzó dentro del repertorio de prácticas educativas del socialismo, quisiera detenerme ahora en la escuela mixta o laica que, como sostiene Marina Becerra, "era graduada y para ambos sexos, lo cual junto a su carácter absolutamente laico, constituía un elemento innovador en Santiago del Estero". ${ }^{71}$ Como sostiene la autora, las escuelas creadas por los socialistas planteaban "una propuesta educativa ideológicamente diferente", al ser escuelas sin religión y sin "los elementos xenófobos y racistas del nacionalismo hegemónico" de las escuelas estatales. Asimismo, estas escuelas se presentaban como instituciones modernas, cuya orientación práctica las diferenciaba también de las escuelas del Estado. $^{72}$

\footnotetext{
69 "La venida del compañero D. Nicolás Repetto a ésta, sus conferencias, consejos y su relación de viaje, nos ha encarrilado hacia la verdadera senda y sabremos aprovechar nuestros esfuerzos, uniéndolos, para que no se pierdan en el vacío", aseguraba uno de los militantes del Centro Socialista de Santiago del Estero. La Vanguardia, 15/06/1901. Una opinión pesimista impregnó, en cambio, la mirada del corresponsal de La Vanguardia sobre la situación del Centro Cosmopolita de Trabajadores, dos meses después del viaje de Repetto de la provincia. La Vanguardia, 3/08/1901.

${ }^{70}$ El Orden, 5/12/1901, 7/12/1901 y 10/12/1901.

${ }^{71}$ Marina Becerra sostiene que desde 1901 los socialistas comenzaron a denominar escuelas laicas o populares a las que anteriormente se llamaban escuelas socialistas. Con esta nueva denominación se aspiraba a "integrar en la escuela docentes y niños de diferentes procedencias, aún cuando sus padres no fueran socialistas, y de ese modo, precisamente, el socialismo podría ir difundiéndose capilarmente e integrándose lentamente en la vida social argentina". BECERRA, ¿Fiestas patrias o fiestas socialistas?..., op. cit., p. 102.

72 Dicha educación práctica hacía alusión a "un modo de aprender que se producía en el mismo trabajo, en el hacer cotidiano, vinculado a aquella deseada identidad socialista, y distinto al modo de aprender abstracto, propio de las escuelas fiscales, que no les serviría a los obreros". BECERRA, ¿Fiestas patrias o fiestas socialistas?..., op. cit., p. 102-103.
} 
Estos atributos que oponían "la escuela laica, práctica, socialista, una escuela renovada, frente a la escuela burguesa, poco práctica, nacionalista e incuso religiosa, del Estado" estuvieron presentes en la escuela laica de La Banda.

En efecto, una característica particular de la escuela laica de La Banda consistía en sus orientaciones pedagógicas: clases al aire libre, conferencias campestres y excursiones, inspiradas fundamentalmente en el movimiento pedagógico cuyas técnicas, procedimientos y situaciones eran de tipo escolanovista. Estas características, sumadas al hecho de que el director de la escuela debió suspender las admisiones en tanto no podía atender la demanda, da cuenta de la importante repercusión que tuvo esta escuela, una de las experiencias pedagógicas más sistemáticas y duraderas del PS en el periodo. ${ }^{73}$

Esta imagen favorable de la escuela se ajustaba a las descripciones de La Vanguardia que afirmaba que "la escuela mixta funcionaba muy bien" y "los padres de familia están satisfechos de la enseñanza que se da en ella", razón que el semanario socialista atribuía a "los esfuerzos y capacidad del compañero Irurzun". Además, advertía que "por ser muchos los pedidos de admisión se ha tenido que suspender hasta el nuevo año escolar para los últimos solicitantes". ${ }^{74}$

Sin ánimo de agotar el tema con estás páginas, me interesa mencionar -siguiendo también a Becerra- que esta experiencia educativa no estuvo exenta de conflictos, tal como el que afloró a raíz de la participación de la escuela en el desfile del 9 de julio. "La tensión afloró en julio de 1905, cuando el director de la escuela decidió hacer participar a la escuela en el acto conmemorativo del 9 de julio, accediendo a una invitación efectuada por el director de la escuela fiscal de La Banda". Esta decisión motivó una serie de disputas que derivaron en expulsiones del PS y del Centro Socialista de Santiago del Estero, como la de Bernardo Irurzun, ya que tal como se entendía, la asistencia de la escuela a la procesión cívica organizada por el Consejo Escolar de la Banda violaba abiertamente los estatutos del partido. $^{75}$

Aunque no podemos ahondar en todas las características e implicancias que entrañaba este conflicto, sí me gustaría subrayar que el mismo permitió entrever las miradas contrapuestas entre los militantes socialistas en torno a la relación con el Estado, la identidad nacional y la vida cívica. De esta forma, mientras algunos sostenían la necesidad de resignificar los festejos patrios, por ejemplo en términos de lucha de clases, otros se mantenían cautelosos frente a estas prácticas y pensaban, en cambio, que los socialistas debían abstenerse de participar de las fiestas patrias. ${ }^{76}$

Por último, interesa señalar que si bien Irurzun fue nuevamente admitido en el seno del socialismo su figura no dejó de generar suspicacias y cuestionamientos. En esos parámetros, podemos situar los comentarios vertidos por La Protesta en el marco de la gira

\footnotetext{
73 Ibid., p. 103-104.

${ }^{74}$ La Vanguardia, 16/07/1903 y 15/08/1903.

${ }^{75}$ Ibid., p. 104-119.

${ }^{76}$ Ibid.
} 
de la Federación Obrera Regional Argentina (FORA) a Santiago del Estero y La Banda en 1907:

\begin{abstract}
Todos conocen el hecho de haber sido la provincia visitada varias veces por los socialistas. Aquí mismo, en Santiago, estuvo establecido Patroni, y es aquí, o mejor dicho en la Banda, distante diez minutos de ferrocarril, donde vive el conocido Bernardo Irurzun, aquel que un día los socialistas de ésta pidieron al partido su expulsión y al que tras varias discusiones decidieron no acceder a ello. Contado Irurzun es actualmente empleado municipal de ésta, gana unos cuatrocientos pesos mensuales y todos los obreros conservan con pena el recuerdo de su actuación, pues el fue que más contribuyó a que la escuela elemental proletaria que funcionaba en ésta, con 85 alumnos, se deshiciera y el mismo centro obrero entrara de lleno en su bancarrota, pues actualmente a más de haberse declarado autónomos, es tal la cobardía que estos hechos han levantado en el espíritu obrero que solo hay afiliados 25 hombres. $^{77}$
\end{abstract}

$\mathrm{Y}$ aunque es cierto que debemos ser cautelosos frente a este discurso que expresaba el interés de los anarquistas por cuestionar la actuación de los militantes del socialismo, también es cierto que dicha narración puede leerse como un testimonio sugerente acerca del grado de rispidez y de tensiones que habían alcanzado las experiencias educativas en Santiago del Estero, reflejadas en el accionar de la escuela laica y de sus máximos dirigentes, especialmente Bernardo Irurzun.

\title{
4. RECAPITULACIÓN Y AVANCE: EN TORNO A LA MILITANCIA OBRERA
}

Las labores de propaganda realizadas por los militantes del socialismo con el fin de atraer a los trabajadores a los centros y convencerlos de la importancia de la transformación social y del valor de la lucha obrera se plasmaron en un extenso conjunto de actividades que incluían conferencias a cargo de destacados líderes obreros, veladas y tertulias literariomusicales, conmemoraciones de efemérides caracterizadas de la cultura obrera, en especial la Fiesta del Trabajo recordada cada 10 de mayo, junto con las iniciativas orientadas a construir bibliotecas y edificar escuelas alternativas a las del Estado.

Pero, ¿hasta qué punto lograron los dirigentes socialistas difundir su propuesta entre los trabajadores? Con ánimo de ofrecer una primera respuesta $y$, sobre todo, abrir líneas de análisis para trabajos posteriores, quisiera sugerir, a modo de hipótesis, que existía una triple distancia en la vida de estos centros obreros. Por un lado, podemos suponer que existían diferencias entre los militantes y los dirigentes del socialismo nacional y los líderes obreros locales. Posiblemente, una segunda distancia separaba a los dirigentes socialistas locales - figuras que generalmente se repetían dentro de las direcciones de los centros y contaban con una trayectoria en el campo asociativo y/o de la prensa obrera - del resto de los asociados. Finalmente, debemos mencionar el profundo contraste entre los militantes (nacionales y locales) y el universo laboral, heterogéneo y segmentado, que no formaba parte de la vida asociativa.

\footnotetext{
${ }^{77}$ La Protesta, 20/10/1907.
} 
En ese sentido, y si recapitulamos lo expuesto hasta ahora, los dirigentes y militantes del socialismo, como Nicolás Repetto, Adrián Patroni, Bernardo Irurzun, que llegaban a las provincias del norte en gira de propaganda y/o invitados a participar en las actividades de los centros obreros, eran personas instruidas, que contaban con un oficio o profesión y disponían de experiencia partidaria en su carácter de candidatos a diputados nacionales y senadores, o al haber ocupado cargos en el Comité Ejecutivo del PS. Por su parte, los dirigentes obreros locales, también eran hombres con educación y experiencia en la vida asociativa, aunque no así en la dirección del PS. Por lo tanto, aunque existían grandes puntos de coincidencia las trayectorias de los dirigentes obreros nacionales y provinciales no era la misma; lo cual resulta completamente lógico. Ahora bien, tampoco las diferencias eran tan marcadas y al menos en líneas generales compartían las premisas relacionadas con el valor otorgado a la asociación y la protesta obrera con vistas a conseguir una sociedad más justa, bandera del socialismo.

En la medida que la composición social de los centros no reconocía una distancia tan marcada entre quienes ocupaban lugares como dirigentes y el resto de los asociados, y apoyados por la propaganda de los líderes nacionales quienes aportaban su experiencia, cultura y reconocimiento, no resulta descabellado pensar que el interés de los militantes socialistas por atraer y convencer a los trabajadores constituía una empresa factible.

Junto con las cercanías relacionadas con la posesión de una profesión u oficio, la educación y la experiencia en la vida asociativa, dirigentes obreros y socios de los centros compartían ciertos hábitos y costumbres, característicos del artesanado y de otros trabajadores vinculados con el comercio, la educación y el mundo de las profesiones. Así, sobre un horizonte con puntos de contacto, los líderes socialistas aspiraban a fomentar comportamientos asociados principalmente con el valor otorgado al ahorro, a la instrucción y a la lectura. La formación de mutuales, gremios y asociaciones de resistencia en el mundo del trabajo, la organización de conferencias y la formación de salones de lecturas, bibliotecas y escuelas constituyeron iniciativas concretas desplegadas por los trabajadores para alcanzar estos fines orientados a estimular la educación y la cultura. Sin embargo, debemos ser cautelosos con el alcance de estas premisas, ya que algunas de las principales estrategias de convencimiento, difusión y cultura de la época, como eran las conferencias y las bibliotecas, que por su temática y objetivos, probablemente interesaban sobre todo a un sector específico de trabajadores que contaba con cierta formación y/o práctica política. ${ }^{78}$

Las actividades educativas y culturales se combinaban con las propuestas dirigidas a fomentar el aprovechamiento del ocio y del tiempo libre de los trabajadores. Así, a la inclinación de los trabajadores al juego, a las tradicionales riñas de gallo y al hábito de la bebida, los socialistas ofrecían fiestas, veladas y tertulias, que incluían obras de teatro, poesía, música y finalmente un baile, probablemente el momento que más atractivo resultaba a los socios. Sin duda, se trataba de una opción que implicaba modificar antiguos

\footnotetext{
${ }^{78}$ Estas prevenciones sobre el alcance de las bibliotecas y las conferencias fueron sugeridas por Ricardo Falcón en un trabajo pionero (FALCÓN, Ricardo, El mundo del trabajo urbano (1890-1914), Buenos Aires: Centro Editor de América Latina, 1986) y recuperadas por MASES. El tiempo libre..., op. cit., p. 78-79.
} 
patrones de sociabilidad y cultura, brindando otras modalidades de entretenimiento vinculadas estrechamente al propósito de propaganda, concientización y difusión del socialismo.

Ahora bien, ¿̇en qué medida consiguieron los socialistas difundir esta alternativa que asociaba estrechamente disfrute del tiempo libre, fomento cultural y propaganda obrera en el mundo del trabajo? Sin el propósito de agotar la explicación con estas páginas, pero sí mostrar algunos aspectos novedosos, me gustaría sugerir que las actividades motorizadas por los centros posiblemente gravitaron en la conformación y difusión de ciertas identificaciones entre los trabajadores. En esa tónica, contar con un espacio propio, recuperar y emplear los distintos repertorios de la cultura obrera -expresados en la elección de himnos revolucionarios, piezas teatrales y declamaciones poéticas de contenido social, números que reiteradamente integraban el programa de las fiestas de los centros-, así como la disertación sobre tópicos usuales del movimiento obrero y la rememoración de las efemérides centrales de la lucha de los trabajadores constituían, a mi entender, factores centrales que podían favorecer la construcción de una militancia e identidad obrera entre los asociados.

No obstante lo anterior, es probable, también, que esta empresa se enfrentara con límites precisos derivados del peso y la propia lógica de la política local, así como de la influencia de otras corrientes ideológicas, especialmente de los contrincantes del socialismo, los católicos, que también disputaron el espacio de los trabajadores, aunque no incursionaron en la agremiación y la protesta obrera. En ese sentido, no debe desestimarse la influencia que alcanzó en las provincias del norte argentino la prédica religiosa, reconocida por los mismos dirigentes socialistas cuando impugnaban la propaganda de los centros obreros de la región por su "excesivo anticlericalismo". Dato comprensible si tenemos en cuenta, como ya se sugirió, la importancia de los sectores católicos en estas provincias y, especialmente, en el ámbito que nos ocupa, el mundo del trabajo.

\section{CONCLUSIONES}

En este trabajo nos propusimos reconstruir y explicar las prácticas de sociabilidad, propaganda y cultura desarrolladas por los centros de trabajadores en el norte argentino. En particular - y tratando de establecer referencias comparativas - indagamos en la composición, objetivos y actividades seguidas por el Centro Cosmopolita de Trabajadores y, más tarde, el Centro Socialista, en Tucumán, así como por los centros obreros de Santiago del Estero.

Integrados y dirigidos sobre todo por trabajadores de oficio, estos espacios otorgaron una importancia creciente a la política, al participar de los comicios municipales e impartir conferencias orientadas a convencer a los trabajadores de la necesidad de inscribirse en los registros cívicos y de votar, y en el caso de los extranjeros de naturalizarse.

De esta forma, los centros obreros asumían los postulados y las consignas del socialismo argentino de la primera década del siglo XX que conferían centralidad a la "acción 
política", entendida primordialmente - sugiere la historiografía - como acción legislativa parlamentaria.

Privilegiada como una vía central para conseguir reformas encaminadas a favorecer el mejoramiento social y económico de los trabajadores, la intervención política debía complementarse con la lucha sindical, arena en la que participaban activamente los militantes anarquistas $y$, por lo tanto, en la cual los socialistas encontraron serios competidores. ${ }^{79}$ Tal influencia concedida a la acción gremial se reflejó en las labores emprendidas por los centros obreros tucumanos y santiagueños que respaldaron e incentivaron las demandas orientadas a conseguir mejores condiciones de vida y de trabajo, así como aquellas que buscaban expresar solidaridad frente a las movilizaciones obreras en otras regiones del país, principalmente en la zona del Litoral y el área pampeana.

Paralelamente a la preocupación por la participación política, complementada con la lucha gremial, los centros de trabajadores pusieron en marcha veladas y tertulias literariomusicales que permitían articular los fines de entretenimiento y de aprovechamiento del tiempo libre con aquellos dirigidos a favorecer la construcción y la difusión de una militancia entre los trabajadores. Compuestas por un repertorio característico de la cultura obrera, expresado en obras de teatro y poesías con contenido social y/o de denuncia, coros e himnos revolucionarios, las veladas incluían también manifestaciones recreativas como rifas $y$, especialmente un baile, probablemente uno de los momentos más ansiados y atractivos de las fiestas.

Además, tal como era lo usual en los festejos obreros, en el transcurso de los mismos uno o más dirigentes tomaba la palabra para dirigirse a los presentes mediante un discurso o conferencia, modalidad ampliamente valorada en la época para instruir y concientizar a los trabajadores. Como señalábamos en el trabajo, las conferencias podían abordar un extenso conjunto de temas, algunos de los cuales remitían a las preocupaciones del socialismo y del movimiento obrero, como asociación y lucha gremial, democracia socialista, teoría y práctica del socialismo, entre otros tópicos especialmente eficaces para transmitir las consideraciones del PS acerca de la importancia de la protesta pero también de la necesidad de participar en política, sobre todo electoral, entendida como una instancia necesaria para la transformación social.

En ese contexto, alcanzó un lugar destacado la Fiesta del Trabajo, percibida por los dirigentes obreros como un acontecimiento propicio para vigorizar las labores de propaganda entre los trabajadores. La conmemoración contaba, por lo general, de dos etapas. Usualmente, primero, los trabajadores se reunían en los espacios públicos como calles y principalmente plazas. Allí escuchaban a los líderes obreros locales y eventualmente a un delegado del PS, especialmente invitado a participar de estos festejos, quienes en sus discursos y conferencias se preocupaban por subrayar las consignas del socialismo y resaltar las conquistas y principales demandas del movimiento obrero con vistas a transmitir un ideario de lucha entre los trabajadores. Con lo cual, era frecuente que explicaran el valor del

\footnotetext{
${ }^{79}$ FALCÓN. Izquierdas, régimen político, cuestión étnica..., op. cit.
} 
10 de mayo, enfatizaran la necesidad de establecer la jornada de 8 horas y cuestionaran las medidas represivas dictadas por el Estado nacional, como la Ley de Residencia.

Posteriormente, tenía lugar una velada en el local de los centros obreros, en donde los asociados y sus familias compartían la celebración a través de un programa compuesto por la representación de obras de teatro, la declamación de poesías y la entonación de coros e himnos característicos de la cultura obrera, mientras los dirigentes impartían discursos para referirse al significado de la efeméride e instar a los trabajadores a continuar su lucha. No era nada extraño, además, que las actividades de instrucción y concientización, condensadas primordialmente en las conferencias, se proyectaran durante los días siguientes al 10 de mayo, probablemente como un modo de aprovechar al máximo la gira de los delegados socialistas.

Finalmente, los propósitos de sociabilidad, propaganda y cultura fomentados a través de veladas y tertulias literario-musicales, y potenciados mediante conferencias, se completaban con los esfuerzos orientados a concretar dos aspiraciones medulares del socialismo y del movimiento obrero. Por un lado, la construcción de una biblioteca que contribuyera a estimular la instrucción y la lectura entre los asociados. Por otro lado, las iniciativas emprendidas para impartir una educación alternativa al Estado. Para lo cual, los centros obreros crearon instituciones novedosas, como la escuela mixta o laica, dependiente del Centro Socialista de La Banda, que brindaba una educación "moderna” y "práctica". Más allá de sus conflictos y del desprestigio que impregnó al último el accionar de su máximo directivo, Bernardo Irurzun, esta institución escolar, fundada en una localidad obrera, tal como se afirmaba en la época, y en la cual el PS alcanzó especial difusión, constituyó una de las experiencias educativas más significativas del socialismo en la región.

Recebido em 10/05/2012

Aceito para publicação em 15/06/2012 